\title{
Dilema Pendidikan
}

\author{
Mastuhu
}

Education is designed to make people prospered and civilized. Among problems of education in Indonesia is, we hardly find someone or a system which could give people a good example in how someone behave and treat each another. Because, education is not only a study from the elementary school to the university, but the most important thing is how education affect our daily life and also in the life of all people in this nation. Education is not just to break the vicious circle of stupid ness, rather, to teach us how to be brightened and unlighted in the hole of life.

D ilema pendidikan yang dimaksud di sini adalah Dilema Membangun Pendidikan Indonesia, bukan dilema membangun pendidikan secara universal yang berlaku di manapun. Indonesia dewasa ini merupakan "negara yang sedang sakit", hampir merata di seluruh bagian tubuhnya: ekonomi, hukum, HAM, pendidikan, KKN, konflik antarsuku, daerah, agama, dan budaya, serta perampokan, kekerasan, pemerkosaan, dan sebagainya, terus menggejala bagaikan tidak berkesudahan dan tidak ada kepastian kapan sembuh. Janji-janji dalam Kampanye Pemilu untuk Calon Anggota Legislatif (caleg) yang lalu dan untuk Calon Presiden dan Wakil Presiden (Capres \& Cawapres) tidak menunjukkan adanya "platform pembangunan Indonesia" yang jelas, menyeluruh, utuh, mantap, dan meyakinkan. Bahkan, dari hari ke hari rakyat disuguhi berita-berita yang menyakitkan hati dan membingungkan. Saat ini sedang gencarnya berita-berita korupsi yang dilakukan oleh beberapa anggota DPR, baik di pusat maupun di daerah. KKN dan ketidakadilan dilakukan oleh hampir semua kantor resmi pemerintah yang seharusnya melayani kepentingan rakyat banyak atau "wong cilik". Perilaku elit politik sangat membingungkan dan sulit dimengerti oleh rakyat, bahkan terkesan kurang bermoral. Kata orang Jawa, "esok dele sore tempe", yang artinya. "pagi hari berbentuk kedelai, sore harinya berbentuk tempe". Kalau dalam arti yang sebenarnya memang bagus, maksudnya kedelai memang diberi ragi agar melalui proses kimia menjadi tempe, yaitu makanan yang lezat dan bergizi. Namun, yang dimaksud dengan sindiran tersebut adalah pernyataan-pernyataan dan janji-janji yang disampaikan oleh para elit politik yang tidak konsisten, mencla-mencle, bahkan kontroversial. Kebingungan rakyat menjadi bertambah hebat ketika rakyat menyaksikan kemewahan sekelompok kecil lapisan atas, berseliweran mobil-mobil mewah, seperti Mercy, Jaguar, dan sebagainya melintas di jalan raya, serta mendengar uang bermilyar-milyar bahkan triliunan yang semuanya itu mestinya untuk membangun kehidupan rakyat, malahan dikorupsi dan tidak jelas penyelesaiannya. Sekedar gambaran, betapa terpuruk pembangunan manusia Indonesia. Menurut Kompas, 
Kamis, 10-7-2003, peringkat Indonesia berada pada nomor urut 112 dari 131 negara; nomor satu Norwegia dan nomor 131 Myanmar. Menurut hasil analisis para pakar ekonomi, hal tersebut disebabkan karena pembangunan hanya mengutamakan pertumbuhan ekonomi bukan memberantas kemiskinan dan tidak terfokus pada pemerataan dan keadilan.

Dilema membangun pendidikan, meskipun disadari bahwa sumber dari segala malapetaka atau penyakit ini adalah kebodohan dan solusi untuk mengatasi kebodohan adalah pendidikan, namun bidang pendidikan bukanlah bidang pembangunan yang berdiri sendiri, tetapi terkait dan bergantung pada suksesnya pembangunan di bidang-bidang lain dalam satu kesatuan sistem pembangunan nasional.

Orang atau kelompok bodoh tidak mampu membedakan mana jalan halal dan mana jalan haram. Mereka tidak mampu memahami penderitaan orang lain akibat perbuatannyà. Mereka juga tidak mengerti bahwa orang tidak mungkin bertahan dalam kekayaan dan kekuasaaan di tengah-tengah rakyat miskin. Mereka tidak mengetahui bahwa di dalam kekayaannya ada hak orang miskin yang harus dikeluarkan zakatnya. Oleh karena itu, yang dimaksud dengan kebodohan di sini adalah lawan dari kurangnya kecerdasan akal, kecerdasan kalbu, kecerdasan sosial-budaya, dan kecerdasan spiritual, yang semuanya itu bersumber dari kurangnya kecerdasan agama. Orang-orang di zaman Jahiliah pada zaman Nabi Muhammad SAW. dulu bukanlah orang-orang yang bodoh akal, tetapi mereka bodoh hati dan bodoh moral. Di zaman modern ini lahir Jahiliah modern yang sulit dideteksi sifatnya, karena dikemas oleh teori-teori akademik tinggi dan "dibungkus" dengan ajaran moral yang bagus.

\section{Dilema Membangun Pendidikan}

Dilema membangun pendidikan Indonesia, dari mana kita mulai dan bagaimana caranya. Beberapa dilema dimaksud antara lain dapat digambarkan dalam uraian berikut:

\section{Antara membangun bidang pembangunan dan mem-bangun clean governance}

Langsung membangun bidang-bidang pembangunan yang dianggap sangat mendesak dan serius lebih dulu, ataukah lebih dulu kita harus membangun clean governance, yaitu membangun sistem pemerintahan yang bersih dan lengkap dengan pembangunan nasional yang baik dan benar, jujur, terbuka, demokratis, efektif, efisien, profesional, dan produktif yang sarat dengan komitmen tinggi, yaitu peduli dan bertanggung jawab dalam melayani kepentingan rakyat. Pada dasarnya rakyat yang membangun negara ini, pemerintah melayani, memfasilitasi, memprovokasi, dan mengadvokasi. Pemerintah tetap memiliki otoritas dan menjadi wasit yang adil, meluruskan yang bengkok, menghukum yang menyimpang atau melanggar, mempercepat yang lambat, dan mengerem yang terlalu cepat. Pemerintah bertangggung jawab dalam skala nasional dan pemerintah berkewajiban mengembangkan kondisi yang stabil, persaingan yang sehat, kreativitas, inovasi, dan kegairahan atau semangat rakyat dalam melaksanakan pembangunan.

Bidang-bidang pembangunan parsial yang dinilai krusial dan mendesak saat ini yang harus dibangun oleh pemerintah adalah: ekonomi, keamanan, hukum, stabilitas politik, dan membangun 
kepercayaan dalam negeri maupun luar negeri. Orang tidak dapat belajar dengan perut lapar, dalam ketakutan, dan dalam ketidakpastian hukum. Para penanam modal tidak mau menanamkan modalnya jika mereka menilai tidak aman dan tidak menguntungkan.

\section{Antara mutu dan perataan pendidikan}

Dalam menghadapi kerasnya persaingan di Abad 21 ini kebutuhan mutu pendidikan sudah tidak dapat ditunda lagi, sedangkan sebagian besar rakyat Indonesia adalah miskin dan hidup di daerah pelosok yang sulit dijangkau. Mereka ini sangat membutuhkan perataan dan keadilan dalam pendidikan. Keduanya, antara mutu dan pemerataan pendidikan, terasa saling tarik-menarik karena adanya pembedaan hidup dalam masyarakat, yang tidak saja beragam tetapi juga terdapat jurang perbedaan yang lebar. Kelompok kecil lapisan atas, elit, kaya, dan intelektual tinggi sangat membutuhkan pendidikan yang berorientasi pada mutu. Mereka hidup dalam era kompetisi yang sangat cepat, keras, tajam, dan kejam; siapa yang bermutu berhak tampil di depan dan siapa yang tidak bemutu terlempar keluar. Menurut penilaian para pakar, $20 \%$ orang Indonesia menguasai $80 \%$ kekayaan negara, sedangkan $80 \%$ menguasai $20 \%$ kekayaan negara. Perspektif ke depannya adalah "Kelompok $20 \%$ " pertambahan jumlah keanggotaannya berjalan lambat bagaikan deret hitung, sebalikya "Kelompok $80 \%$ " pertambahan jumlah keanggotaannya berjalan cepat bagaikan deret ukur. Kemampuan mengakses sumber-sumber pendidikan bermutu bagi "Kelompok $20 \%$ " berjalan amat cepat dan bervariasi bagaikan deret ukur, sebaliknya kemampuan "Kelompok
$80 \%$ " berjalan lambat dan kurang bervariasi bagaikan deret hitung. Dengan demikian, jurang perbedaan semakin melebar; dalam pada itu kemampuan pemerintah dalam mempersempit jurang perbedaan melalui penataan institusi-institusi dan peraturan perundang-undangan berjalan lambat dan sering ketinggalan. Hal tersebut dapat membawa lahirnya model kepemimpinan oligarki, yaitu kepemimpinan oleh sekelompok kecil, elit, kaya, pandai, dan eksklusif. Kekuasaan yang semakin besar ceriderung semakin korup dan mementingkan kepentingan kelompoknya sendiri, sehingga eksploitasi dan ketidakadilan akan semakin nyata.

\section{Pendidikan untuk siapa, untuk pemerintah, rakyat, pasar, bos- kah?}

Singkatnya, "Pendidikan untuk yang belajar atau untuk pihak yang berada di luar mereka?". Negara sangat mendambakan warga negara yang tangguh dalam mencintai dan membela negara: "Padamu Negeri Aku berjanji, Padamu Negeri Aku Mengabdi, dan Padamu Negeri Jiwa Raga Kami". Hal tersebut mencerminkan keinginan negara agar pendidikan mampu menghasilkan warga yang patuh pada negara, sebaliknya rakyat mendambakan agar pendidikan dapat membebaskan nasib mereka yang selama ini terpuruk dan terbelenggu. Pasar dan Bos sebagai pengguna jasa pendidikan mendambakan pekerja-pekerja (lulusan sekolah) yang cakap, produktif, dan berkualitas. Masyarakat mendambakan lulusan sekolah yang baik, saleh, dan mampu,membangun masyarakat dalam tata kehidupan yang nyaman, bersih, dan damai. Banyak harapan dari pengguna jasa pendidikan, karena beragam kebutuhannya, belum lagi 
keinginan kelompok-kelompok agama yang berbeda-beda yang juga mempunyai paradigma dan kebutuhan sendiri-sendiri.

Tidak mudah menyelesaikan "tarik-ulur" untuk memenuhi kepentingan yang berbedabeda. Namun, yang jelas tugas dan fungsi pendidikan pada hakikatnya hanya satu yaitu "MEMANUSIAKAN MANUSIA", artinya pendidikan diharapkan mampu mengangkat hakikat dan martabat manusia (human dignity). Manusia yang demikian ini adalah manusia mandiri yang tidak hanya mementingkan diri sendiri, tetapi juga mementingkan kepentingan hidup bersama, berorientasi pada perilaku produktif dan kreatif, serta mempunyai komitmen, peduli, dan tangggung jawab terhadap pembangunan masyarakat, bangsa, dan negaranya.

\section{Penyelenggara pendidikan}

Seiring dengan dilema ke-3 di atas, pendidikan sebaiknya diselenggarakan oleh siapa? Siapa yang seharusnya lebih berperan dalam menyelenggarakan pendidikan, "masyarakat" atau "pemerintah"?

Mengingat berbagai ragam kebutuhan dan jurang perbedaan yang lebar antar kelas sosial dalam masyarakat, maka posisi dan peran pemerintah dalam menyelenggarakan pembangunan pendidikan merupakan suatu keniscayaan (keharusan), bahkan sampai saat ini peran dan otorita pemerintah dalam menyelenggarakan dan mengontrol pendidikan sangat besar dan menentukan.

Sebaliknya, tuntutan zaman menghendaki masyarakat berperan lebih besar dalam menyelenggarakan pendidikan. Kenyataannya, ketika otonomisasi dan desentralisasi digulirkan dan dipercayakan kepada lembaga-lembaga penyelenggara pendidikan hasilnya belum meyakinkan, banyak di antaranya yang belum jelas benar memahami dan memanfaatkan peluang "otonomisasi" dan "desentralisasi" dimaksud. Kualitas pendidikan yang diselenggarakan oleh pemerintah rata-rata lebih unggul daripada yang diselenggarakan oleh masyarakat. Secara kuantitatif lembaga-lembaga pendidikan yang diselenggarakan oleh swasta lebih banyak daripada yang diselenggarakan pemerintah, namun secara kualitatif lembaga-lembaga pendidikan yang diselenggarakan pemerintah lebih baik.

Idealnya, dalam pembagian kerja penyelenggaraan pendidikan antara pemerintah dan masyarakat adalah sebagai berikut; Masyarakat yang menyelenggarakan pendidikan, karena itu mutu pendidikan menjadi tanggung jawab masyarakat. Namun, dana dan sistem pendanaan (funding system) berasal dari pemerintah dan pemerintah pun mengakui hasil pendidikan oleh masyarakat tersebut. Dalam hal ini, pemerintah berhak minta pertanggungjawaban akan mutunya, sebab pemerintah bertangggung jawab akan mutu pendidikan nasional di mata dunia internasional. Konsekuensinya, pemerintah berhak menghentikan upaya pendidikan yang tidak bermutu dan mengganggu atau membahayakan negara, misalnya menentang Pancasila, menurunkan harkat dan martabat bangsa, memicu faham kekerasan, kesesatan, dan sebagainya. Pemerintah berkewajiban memberikan political will dan mendorong kegairahan masyarakat dalam mengembangkan pendidikan. Untuk daerah-daerah terpencil, pemerintah berkewajiban mensponsorinya lebih dahulu sampai masyarakat tersebut mampu mengambil alih secara mandiri. Masyarakat berkewajiban memberikan laporan kepada pemerintah dan secara terbuka pula, para penyelenggara unit pendidikan memberikan tanggung jawabnya 
'kepada seluruhıstakeholders, penyandang dana; idan;pengguna jasa pendidikan,

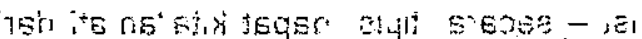

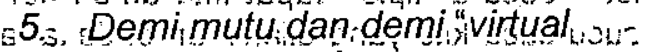

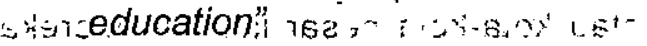

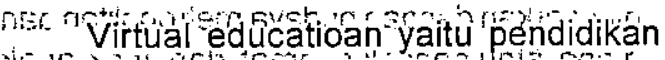
yang semestinya "Bidang pendidikan merupákan "bídang kerja akademik yang

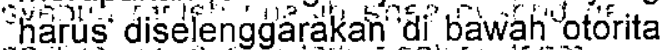
"akademik atálu bidang Kerja pemérintahan yang harus dilaksanakan di bawah otorita -kekuasaan. Mengingat tuntutan globalisasi dan kemajuan IPTEK yáng cepat sebaiknya bidang pendidikan diposisikan sebagai kerja akademik, sedang pemerintah tetap dalam

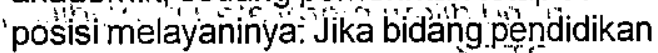
menjadi bidang kerja akademik;' ákibatnya :adalah guru dan tenaga-tenaga edukatif lainnya menjadi tenaga-tenaga profeșional , dan bukan sekedar "pegawai" seperti sekarang ini . Ciri-ciri yang membedakan tenàga profesional dan tenaga, non- professional. (misalnya tukang) antara lain - sebagai berikut: Keahlian tenaga professional dilandasi oleh suatur teori ilmiah yang -mempengaruhi mutu kerjanya Secara sistematik mereka harus terus-menerus -mengembangkan keahliannya Tenaga profesional dituntut memiliki komitmen yaitu kejujuran , kepedulian, dan tanggung,jawạb terhadap kliennya. Meréka harus tahu apa yang dibutuhkan oleb kliennya yapg, boleh -jadinkljennya tidak tahu apa yang sesungguhnya dibutuhkan Kontrak kerjanyaitidak sebatas pada apa honor-yäng -diterimanya jal itu semua berbeda dengan -tenaga tukang yang-keahliannya dilahirkan r.darilatihan, atau magang di mana ja harus r.banyak berlatih untuk memantapkan ketrampilannya dan ia harus jujur unntuk smenjaga kepercayaan. Namun semuayang nmereka kerjakan atau lakukan ditentukan oleh bos yang membayarnya dan kontrak nkerjanyarsebatas pada, honor yang

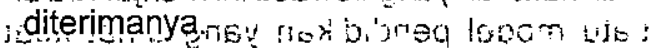
misesDengan katalain; itidakısemua:orang rdapatmenjadi guru dan pengelolas sekolah. Mereka harus melalui.pendidikan akademik. Keahliannya juga tidak sebatas kemampuan fisiknya banyak profesionalis yang - kekuatan fisiknya memukau namun 4 kekuatan intelektual dan kearifannya masin

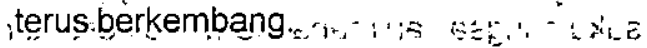

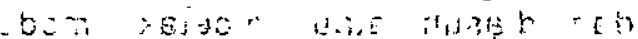
6. Antara mengembangkan "budaya "r. daerah" dan "budayanasional"

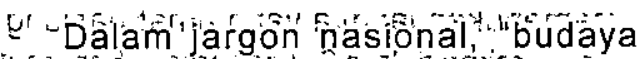
niasionaladalah puncak dari búdaya daerah".

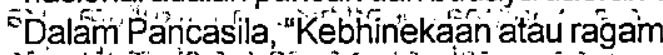

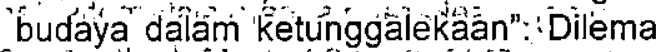

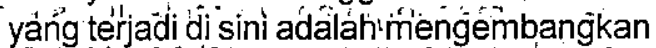

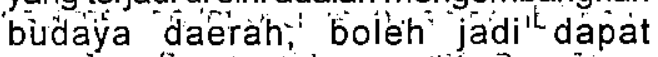
"memperlemah budaya nasionál. Begitũ juga sébaliknyâ, mèngembanğkan budaya nasional, boleh jadi memperlemanh budaya daêrah. Méngamati perjalahan bangsa

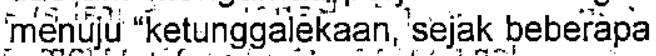
jahưn terákhir ini, kira-kira 5-6 tähun lalu,

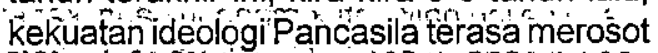
dan kưráng berbobot seiring dengan itu, perkembangan bǘdáya nasionaljugaterasa

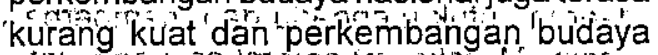

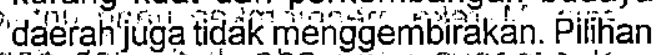

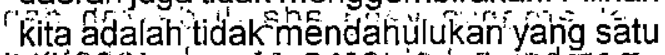
dán membelakangkan yang lain Têa i, kita "mengembang simultan karena kêduanya merniliki "hubugan yang "resiprokal, saling menyebabkan dan mengaki inatkan dân

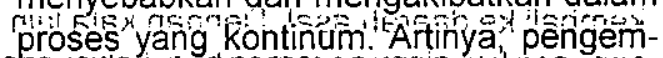
bangan budaya nasionap tidak dapât

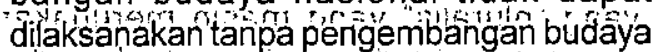

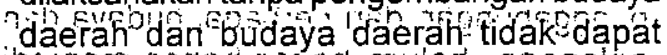
idikembañón

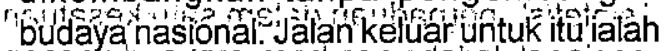

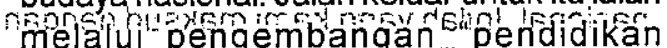

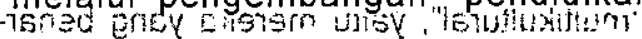


multikultural" yang dewasa ini menjadi salah satu model pendidikan yang amat kuat dalam memasuki "network age", baik dalam dalam jaringan kerjasama nasional maupun kerjasama internasional atau global.

Pendidikan multikultural menuju persatuan dan kesatuan kebangsaan atau nation state tanpa mengorbankan jati diri budaya daerah atau lokal masing-masing suku bangsa dari mana mereka dibesarkan dan diasuh atau "dicetak" model kepribadiannya. Tidak mudah menyelenggarakan pendidikan multikultural dan memerlukan jangka yang amat panjang diperkirakan dalam 2-3 generasi - baru mulai terasa dampak pendidikan multikultural, jika kita sejak sekarang secara sistematis dan intensif mengerjakannya melalui sistem pendidikan nasional. Dikatakan demikian, karena generasi sekarang, yaitu mereka yang dilahirkan sampai 10-20 tahun sebelum akhir abad ini mașih terlalu kental dengan budaya primordialnya. Kota-kota besar, seperti: Jakarta, Bandung, Surabaya, Yogya, dan sebagainya, merupakan tempat yang paling baik untuk mencari uang, karier, dan mengadu nasib. Oleh karena itu, kotakota besar selalu diserbu oleh orang-orang daerah untuk mengadu dan memperbaiki nasib. Mereka mengirimkan uang untuk keluarganya yang ada di daerah dan membawa keluarga atau kerabatnya sesuku, sedaerah, sebudaya, dan seagama, jika ada peluang kerja di kota. Banyak pula di antara mereka yang merencanakan untuk menikmati hari tuanya kembali ke daerah asal. Dengan kata lain, apa yang kita alami sekarang baru kehidupan yang "pluralis" yang masih merupakan penggabungan dari berbagai budaya dan golongan, belum benar-benar menjadi "sintetis", perpaduan dalam satu kesatuan nasional. Inilah yang kami maksud dengan "multikultural", yaitu mereka yang benar- benar hidup dalam "puncak budaya daerah". Gejala-gejala multikultural mulai ada - exist - secara "tipis" dapat kita "amati dari cucu-cucu kita yang dilahirkan di Jakarta atau kota-kota besar lainnya. Mereka dibesarkan dengan budaya metropolitan dan global atau dapat kita amati dari anak-anak yang dilahirkan dari perkawinan antarsuku dan budaya serta diasuh dalam budaya metropolitan dan global. Konsep pendidikan multikultural yang mantap harus segera kita temukan dan kita jadikan agenda kerja pendidikan nasional.

\section{Antara mendahulukan pendidikan moral atau pendidikan IPTEK}

Di dalam masyarakat masih terdapat "pilihan dikotomis" antara mendahulukan pendidikan moral (akhlak) dan pendidikan ilmu. Kelompok-kelompok agama menekankan pentingnya landasan atau penguatan iman, takwa, dan moral sebelum penguatan ilmu. Sebaliknya, kelompok ilmuan (umum) menekankan pentingnya landasan atau penguatan ilmu sebagai modal untuk menyongsong kehidupan ke depan. Meskipun demikian, keduanya disadari sebagai "two in one" bekal memasuki kehidupan modern. Namun dalam kenyataannya, model pendidikan yang menyatukan keduanya masih amat sederhana, terpisah dan parsial. Pendidikan agama sebagai sumber utama penguatan moral, baik yang diajarkan disekolahsekolah umum maupun sekolah-sekolah agama, belum menyentuh secara substansial dan fungsional pendidikan umum. Sebaliknya, pendidikan dan pengajaran mata pelajaran umum (ilmu-ilmu sekuler) belum menyentuh secara substansial dan fungsional pengajaran agama. 
Ketika "agama" bertemu dengan "ilmu" selalu terjadi sedikitnya empat hal, yaitu: "konflik" karena masing-masing mempunyai tujuan dan kepentingan berbeda; "dialog" karena masing-masing mempunyai kelebihan yang saling diperlukan dalam proses dinamikanya: "Agama tanpa ilmu akan lumpuh dan sesat, ilmu tanpa agama cenderung anarkhis dan menghalalkan segala cara"; "inter independensi", masingmasing memiliki daerah kerja dan otoritas. Dalam kasus tertentu, agama akan lebih efektif dan efisien jika tidak "diganggu" oleh ilmu, juga sebaliknya, ilmu akan lebih bebas melaksanakan fungsinya jika tidak "terbelenggu" oleh ajaran agama. Dan, terakhir adalah "integratif", di mana banyak kasus dalam kehidupan nyata yang memerlukan kerjasama secara integratif antara keduanya. Banyak ahli agama yang ilmuan yang lebih menghargai "aplikasi ajaran agama (iman) atau perilaku keberagamaan sosial yang semestinya virtual religious behaviour - dalam membangun kehidupan bersama" daripada "iman masing-masing orang", karena hal ini merupakan kepercayaan yang bersifat pribadi: "bagimu agamamu dan bagiku agamaku".

Empat hal tersebut akan selalu muncul tergantung pada kasusnya dan wawasan atau kedalaman pemahaman agamawan dan ilmuan yang menghadapinya. Oleh karena itu, perlu dikembangkan pendidikan lintas agama dan lintas budaya serta paradigma baru pendidikan agama yang diajarkan di sekolah-sekolah umum maupun pendidikan umum yang diajarkan di sekolahsekolah agama.

\section{Rekapitulasi dan Solusi}

Merekap 7 (tujuh) dilema tersebut, kiranya dapat kita simpulkan bahwa tidak satupun yang antagonistis, yang harus dipilih satu dan meninggalkan yang lain. Oleh karena itu, masalahnya adalah bagaimana melakukan pilihan yang tepat dan strategis serta bijaksana dalam tindakan, di mana semuanya mengacu demi kesembuhan dan kejayaan bangsa dan negara. Berikut ini "ditawarkan" solusi umum sebagai berikut:

Pertama, "Clean Governance". Tegakkan pemerintahan yang bersih, adil, jujur, dan profesional, lengkap dengan pimpinan yang memiliki sifat kenegarawanan yang hebat dan berpandangan luas. Inti krisis yang dihadapi oleh bangsa ini adalah "krisis kepercayaan" dan tidak adanya pemimpin yang memiliki sifat kenegarawanan yang benar-benar mempunyai komitmen, yaitu jujur, peduli, dan bertanggung jawab atas perbaikan dan kemajuan rakyat, serta bebas dari KKN.

Kedua, "Ekonomi Rakyat". Rakyat yang lapar tidak mungkin dapat belajar. Kemiskinan memungkinkan mereka menempuh semua cara agar dapat makan, berpakaian, dan bertempat tinggal. Baru, kalau hal-hal ini terlampui secara standar, bebas dari kemiskinan, mereka dapat memikirkan pendidikan, baik bagi anakanaknya maupun bagi dirinya sendiri. Tentu, harus diputuskan "ukuran standar" bebas miskin secara nasional.

Ketiga, "Keamanan, Hukum, dan Stabilitas Politik". Sama seperti orang miskin, orang yang tidak aman, hidup dalam ketakutan, dan tidak berkepastian hukum dan politik, tidak mungkin mampu memikirkan pendidikan. Selain itu, keamanan, kepastian hukum, dan stabilitas politik merupakan kondisi minimal untuk menumbuhkan kepercayaan, baik dalam negeri maupun luar negeri, untuk menggalang kerjasama membangun bangsa ini. 
Jika tiga hal yang merupakan persayaratan minimal dan standar dilampaui, kita dapat membangun pendidikan nasional dengan sebenarnya. Meskipun demikian, hal ini tidak berarti kita tidak melaksanakan pembangunan pendidikan ketika kita dalam proses membangun tiga persyaratan minimal dimaksud.

Tony Blair dalam posisinya sebagai Perdana Menteri Inggris, ketika posisi negaranya sudah mencapai predikat "negara maju" mengatakan: "I have three burning issues: 1st Education, 2nd Education, and 3rd Education" untuk membawa dan menjaga kejayaan Inggris selanjutnya. Semoga.....

\section{Daftar Pustaka}

Azra, Azyumardi, Membangun kembali Indonesia Tunggak Eka, Makalah disampaikan dalam diskusi pakar PPP, tanggal 13-11-2001 di Jakarta.

Barbour, lan G. 2003, Juru Bicara Tuhan: Ketika Agama bertemu dengan IImu - antara sains dan agama, IKAPI.

Freire,Paulo, 1974, Cultural Action for Freedom, USA, Penguin Book. 1974, Paedagogy of the Oppressed, USA, Penguin Book.

Hall, Kenneth R., The Western Academic and Ascend Universities: Attemps to create a less western - based academic identity in Indonesia, Makalah disampaikan di UIN Jakarta tanggal 15-6-2004 di Jakarta.

Hefner, Robert W. 2001, Civil Islam, Muslim and Democratization in Indonesia, Princeton University Press.

Mastuhu, 2000, Politik Pendidikan Indonesia Menyongsong abad 21 Berbagai dilema dalam menyelesaikan masalah Pendidikan Indonesia, dalam buku kenangan Prof. DR. Machtuchah Yusuf ke 80, Jakarta.

,2003, Menata Ulang Pemikiran Sistem Pendidikan Nasional dalam Abad 21 - The New Mind Set of National Education in the 21 st Century, Yogyakarta: UII - Safiria Insania Press, Cet ke-2.

1999, Memberdayakan Sistem

Pendidikan /slam, Jakarta: PT. Logos Wacana IImu, Cet.Pertama.

Robert Kiyasoki, 2001, Rich Dad, Poor Dad, Apa yang diajarkan orang kaya pada anak-anaknya tentang uang yang tidak diajarkan oleh orang miskin dan kelas menengah, alih bahasa Purnomo, Cetke-17, Jakarta: PT Sun.

Setjen Dewan Ketahanan Nasional, Workshop mengenai Isu Strategis dan Penyelesaiannya, dibidang Politik, Hukum, Ekonomi, SosBud, Agama, Pendidikan SDA dan Lingkungan, Bulan Mei - Juni, 2004 di Jakarta. 